\title{
Biblioteki i bibliotekarze w przestrzeni filmowej (reprezentacje i konotacje)
}

\begin{abstract}
Gierszewska Barbara Lena, Biblioteki i bibliotekarze w przestrzeni filmowej (reprezentacje $i$ konotacje) [Libraries and Librarians in the Film Space (Representations and Connotations)]. „Przestrzenie Teorii" 32. Poznań 2019, Adam Mickiewicz University Press, pp. 213-238. ISSN 16446763. DOI 10.14746/pt.2019.32.11.

Using selected films, a picture of library buildings and their interiors from the 1950s to the present day has been created. The vast majority of libraries are "temples of knowledge", and librarians (invariably educated and relatively unattractive women) are the "guardians" of the collections. Contemporary film rarely depicts shows libraries as a system not to be overestimated "in the times of smart phones and social media". Filmmakers' attention is drawn mainly the interesting architecture of library interiors to, in which "library scenes" are set, hence the aura of library is seldom perceptible. Książnice is often the backdrop or part of the story told in the film, and sometimes reveal other features such as the genre and other books important to the characters.
\end{abstract}

KEYWORDS: film space, film library, librarian as a film hero

Pisarze, scenarzyści i reżyserzy filmowi oraz artyści plastycy stosunkowo często wykorzystywali (i wykorzystuja) w swej twórczości obraz książki i związane z szeroko rozumianą lekturą miejsca, ze szczególnym uwzględnieniem książnicy, domowej biblioteki, księgarni, antykwariatu etc. oraz pracujących tam ludzi. Mogłoby się zatem wydawać, że skoro to niemal tradycja powracania do przepracowanego tematu oscylującego wokół środowiska czytelniczego, zatem każdy mistrz powinien oryginalnie "wkomponować" we własne dzieło związane z literatura motywy. Niestety, tylko sporadycznie „sceny lekturowe”, „sceny biblioteczne”, „sceny w księgarni" itd. obecne w literaturze, filmie i innych sztukach wizualnych wykraczają poza granice stereotypowego myślenia o tej przestrzeni. Na ogół sa to figury książki, dzieła literackiego, biblioteki (bibliotekarza), księgarni (księgarza, bukinisty, antykwariusza), które się powtarzaja i powielają utrwalone w naszej pamięci klisze co do treści tychże. Można więc mówić o podobieństwie kluczowych motywów związanych zwłaszcza z postrzeganiem bibliotek i księgarń oraz pracujacych tam ludzi, jak również książek (konkretnego dzieła). Najczęściej stanowią bliższe lub dalsze tło literackich i filmowych narracji, czyli pełnia funkcję scenograficznego detalu. Czasami biblioteka bywa jednak ciagiem obrazów w umyśle bohatera (bohaterów), ważnym polem dla budowania narracji i wtedy wymyka się trywialnemu stwierdzeniu, jak pisał Jacek Ostaszewski, że 
„zdarzenia filmowe zawsze muszą być umiejscowione w jakiejś konkretnej przestrzeni" ${ }^{1}$.

Zamierzeniem artykułu jest przedstawienie sposobów patrzenia reżyserów filmowych na bibliotekę i bibliotekarza. Temat ten nie został dotychczas poddany szerszej analizie, poza kilkoma materiałami w piśmiennictwie księgoznawczym, z których jawi się ogólny obraz biblioteki jako instytucji i osób wybierających zawód bibliotekarski. W wielu przypadkach rozpoznano rzeczywiste książnice użyte na potrzeby konkretnych filmów i podjęto próby porównawcze. Mnie bardziej interesowały sceny biblioteczne, w których mamy do czynienia z wzbogaceniem wizerunku zarówno pracownika biblioteki, jak i książnicy, w stosunku do obiegowego wyobrażenia, dzięki czemu film zyskuje na oryginalności czy choćby wpływa na szczegóły treściowe lub formalne. Pamiętać jednak należy, że każde wnętrze biblioteczne jest nacechowane podobną symbolika (regały biblioteczne, książki, miejsce dowodzenia bibliotekarza, prymat ciszy), co może służyć budowaniu przestrzeni diegetycznej (np. konotującej powierzchnie labiryntowe, z sekretnymi przejściami, zdumiewającymi dziwnościa, tajemnica), ale i przeszkadzać z powodu powtarzalności układu i rozpoznawalnych w działaniu funkcji w społeczeństwie. W przypadku biblioteki jako przestrzeni filmowej ma zastosowanie pojemna znaczeniowo definicja Alicji Helman, w myśl której:

Przestrzeń filmowa jest nie tylko przestrzenią obrazu, lecz także przestrzenią opowiadania, dana jest widzowi nie w sposób monumentalny, lecz poprzez sukcesywne następstwo kadrów. Stąd częściej niż o reprodukowaniu przestrzeni teoretycy mówią o jej oznaczaniu, traktując poszczególne obrazy jako znaki, których komplet reprezentowałby cała przestrzeń ${ }^{2}$.

Warto w tym miejscu pochylić się nad nowoczesnym rozumieniem terminu biblioteka, gdyż różni się znacznie od klasycznej definicji. Właściwie powinno dziwić, że społeczeństwo Sieci nadal widzi w bibliotece przede wszystkim budynek, w którym są gromadzone i udostępniane wytwory myśli ludzkiej w postaci materialnej (tradycyjne: książki, czasopisma, mapy) lub cyfrowej (kasety, płyty, dyski). Pośrednikiem w dotarciu do poszukiwanego dokumentu nadal bywają bibliotekarki - utrwalone w pamięci czytelników jako kobiety nieatrakcyjne i mało empatyczne ${ }^{3}$. Naturalnie ci, którzy chodzą

${ }^{1}$ J. Ostaszewski, Paradoksy przestrzeni filmowej, „Kino” 2001, nr 2, s. 55.

${ }^{2}$ A. Helman, Przestrzeń filmowa, [w:] Stownik filmu, red. R. Syska, Kraków 2010, s. 381.

${ }^{3}$ Renata Malesa przeprowadziła ciekawe badania nad przyczynami postrzegania zawodu bibliotekarza w XXI wieku jako nudnego i mało atrakcyjnego na rynku pracy oraz niesatysfakcjonującego dla większości uprawiających tę profesję. Prognozy, że coś się zmieni na lepsze, są nadal mało prawdopodobne, gdyż - jak wskazuje autorka: „Bibliotekarz powinien starać się być bardziej widoczny w społeczeństwie, a zwłaszcza wśród użytkowników biblioteki”, co nie udaje się często z powodów charakterologicznych. „Współczesny bibliotekarz - czytamy 
do bibliotek, mają świadomość zmian, jakie nastapiły w samych bryłach architektonicznych takich obiektów, jeśli chodzi o design, wyposażenie, zbiory, co zresztą zostało utrwalone w filmowych scenach bibliotecznych. Podobnie ma się rzecz z postrzeganiem pracowników tych instytucji, którzy już dawno przestali być li tylko katalogującymi, wypożyczającymi, informującymi o zbiorach i skupionymi na działaniach prewencyjnych. Zadania współczesnych bibliotekarzy (już nie do końca jest to termin przystający do nowych funkcji), z powodu rewolucji informatycznej uległy przesunięciu, wymagaja wielu nowych kompetencji, co jest na ogół doceniane przez grupę bardziej zaawansowanych w poszukiwaniach klientów książnic, info- i mediatek, jakkolwiek nie ma to większego przełożenia na mitologizację charakteru bibliotekarki i jej aparycji.

Uwagi wstępne nt. przesunięcia miejsca biblioteki i umownego potraktowania „świata bibliotek” we współczesnej komunikacji społecznej wydawały mi się ważne, aby rozwinąć temat właściwy, tzn. pokazać obraz biblioteki w filmie (głównie fabularnym) czy szerzej: w przekazie audiowizualnym. Nie chodzi jednak o dokładną analizę ilościową i jakościową całej spuścizny kinematograficznej w powiązaniu z bibliotekami, gdyż problem został już rozpoznany jakiś czas temu przez bibliotekarzy (przemyślenia autorów obcych ${ }^{4}$ i polskich ${ }^{5}$ są imponujące), historyków sztuki i architek-

dalej - musi się dobrze czuć w różnorodnych rolach. Powinien być badaczem, doradca, planista, menadżerem, nadzorca, przywódca, członkiem zespołu, osobą rozwiązująca problemy, nauczycielem i ciagłym uczniem". Trudno nie zauważyć, że są to bardzo wysokie wymagania, za którymi bynajmniej nie nadążaja płace. R. Malesa, Zawód bibliotekarza. Między przeszłościa a przyszłościa, „Folia Bibliologica” 2006/2007, t. 48/49, s. 80, 86.

${ }^{4}$ Zob. Movie librarians. Notable librarians \& librarians in films, $<$ http://home.earthlink. net/ movielibrarians/> [dostęp: 20.08.2019].

${ }^{5}$ Uznanie należy się zwłaszcza Piotrowi Marcinkowskiemu, którego ciekawe spostrzeżenia wokół bibliotekarzy jako budowniczych nowego ładu medialnego są bardzo przekonujace, choć nadal pesymistyczne. Cenię też wieloaspektową analizę bibliotek i bibliotekarzy w przekazach literackich i filmowych tego autora. Zob. tegoż, Autostereotyp czy samouwielbienie, czyli jak sami siebie widzimy, [w:] Przyszłość bibliotek w Polsce, red. J. Sadowska, Warszawa 2008, s. 145-152; tegoż, Bibliotekarz. Stereotyp czy wizerunek?, [w:] Tradycja i nowoczesność bibliotek akademickich, Rzeszów 2005, s. 107-115; tegoż, Czy bibliotekarze będa budowniczymi społeczeństwa informacyjnego w Polsce?, „Bibliotekarz” 2006, nr 11, s. 3-8; tegoż, Jak zmienić wizerunek bibliotekarza?, „EBIB” 2006, nr 2, <http://ebib.info/2006/72/marcinkowski.php> [dostęp: 21.08.2019]; tegoż, Czy bibliotekarz zna język czytelnika?, „EBIB” 2005, nr 4, <http:// ebib.oss.wroc.pl/2005/65/marcinkowski.php> [dostęp: 21.08.2019]; zob. tė̇: M. Parnowska, O bibliotekarzach, bibliofilach, bibliomanach, bibliofagach i bibliotafach, „Twórczość” 2008, R. 64, nr 1, s. 146-148; A. Śniechowska-Karpińska, Zgryźliwa, podobna do sępa, czyli: kto rzqdzi w bibliotece $w$ Hogwarcie?, „EBIB” 2004, nr 4, <http://ebib.oss.wroc.pl/2004/55/sniechowska.php> [dostęp: 13.08.2019]; M. Zygmunt, Mysz uzbrojona w mysz, czyli o stereotypie bibliotekarki w społeczeństwie informacyjnym, „Biuletyn Informacyjny Biblioteki Narodowej” 2002, nr 1, s. 33. 
tury ${ }^{6}$. Ustalenia moich poprzedników co do usytuowania i poszerzenia tradycyjnych bibliotek o kontekst cyfrowy i wirtualny, sa tym bardziej nie do przecenienia, gdyż są to głównie głosy bibliotekarzy, często z dystansem do rozumienia problemu przez informologów ${ }^{7}$. Nasuwają mi się jednak raczej mroczne refleksje dotyczące rozumienia przez ludzi filmu zmian w bibliotekarstwie, które byłyby widoczne na ekranie. Zresztą w filmach tematycznie powiązanych z uniwersytetami, dotyczących środowisk studenckich (często $\mathrm{w}$ charakterze przestrzeni artystycznej) widać w tle nowoczesne biblioteki, nie pozostawiając wątpliwości, że są ważnymi ogniwami systemu komunikacji społecznej, gdyż proponują dostęp do uporządkowanych i wiarygodnych informacji (i/lub zbiorów), co w internetowym chaosie jest wartością trudną do przecenienia.

Powracając do meritum, mam nadzieję, że udało mi się w artykule poddać szerszej analizie filmy, w których biblioteka była osią fabuły, miała wpływ na pogłębienie transparentności narracyjnej lub okazała się znaczącym korelatem stanów emocjonalnych postaci. Obejrzane filmy (kilkadziesiąt tytułów fabularnych, kilka dokumentów) w dużym stopniu potwierdziły znaną wcześniej tezę, że w autorskim kinie, w serialach, jak również w kreskówkach dominuje dość przygnębiajacy obraz biblioteki i zatrudnionych tam pracowników (głównie kobiet), ludzi bez polotu, poirytowanych nisko płatną praca, życiowo przegranych. Jednocześnie były wśród nich tytuły, które upoważniają do bardziej optymistycznego stwierdzenia, że kino zawsze próbowało polemizować ze stereotypowym wizerunkiem bibliotekarki/bibliotekarza oraz biblioteki jako konserwatywnej instytucji publicznej. Sądzę, że udało się w niniejszym tekście choć w jakimś stopniu sproblematyzować temat i poddać oglądowi te sytuacje, w których filmowcy mieli swoje powody, aby w ten, a nie w inny sposób wyeksponować daną bibliotekę, gdyż tego wymagała fabuła, lub uznali, że z powodów stylistycznych, estetycznych, topografii miejsca warto było poddać percepcji widza np. fasadę budynku, wnętrze czy jego część. W wielu przypadkach w sposób zadowalający udało

${ }^{6}$ Przykładowo Irma Kozina zwróciła uwagę na konieczność nowego spojrzenia na bibliotekę na miarę XXI wieku. Zob. tejże, Rola intymności $w$ architekturze bibliotek, [w:] Światta biblioteki otwartej. Rola biblioteki akademickiej $w$ ksztattowaniu społeczeństwa obywatelskiego, red. D. Pawelec, M. Waga, J. Witek, Katowice 2016, s. 54-61. Ważność biblioteki jako miejsca pracy akademickiej podkreślał m.in. P. Jędrzejko. Zob. tegoż, Zamknięci w bibliotece, czyli Rozważania o metanarracjach i naukowych wizjach świata, [w:] Światta biblioteki otwartej..., s. 34-53.

${ }^{7}$ M. Winiarska, E-film jako najnowszy sposób percepcji sztuki filmowej, [w:] Internetowe gatunki dziennikarskie, red. nauk. K. Wolny-Zmorzyński, W. Furman, Warszawa 2010, s. 219-225; J. Zajdel, Hipertekstualna struktura polskich internetowych serwisów filmowych, [w:] Internet, społeczeństwo informacyjne, kultura, red. nauk. A. Kiepas, M.S. Szczepański, U. Żydek-Bednarczuk, Tychy 2006, s. 107-117. 
się zobaczyć bibliotekę jako przestrzeń niejednorodna, wiele wnosząca do filmu, a tym samym odpowiedzieć na pytanie, dlaczego akcja danej sceny dzieje się właśnie w bibliotece, a nie gdzie indziej i dlaczego w takiej akurat kolejności w stosunku do innych ujęć filmowych.

\section{Świat biblioteki w filmie}

Zacznę od definicji biblioteki rozumianej „jako uniwersum tekstów i symbol dokonań autorskich"8. Wydaje się ona bardziej przystająca do współczesności, gdyż pozwala na szersze pojmowanie zbiorów bibliotecznych, zaliczając doń wszystkie przekazy treściowe, które, jak wskazuje Maryla Hopfinger, „przetrwały próbę czasu, zostały uznane za dzieła i arcydzieła,

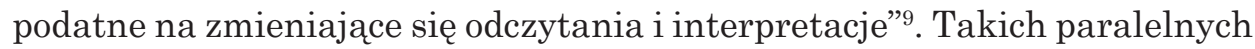
definicji biblioteki można zresztą przytoczyć wiele. Zawierają różne propozycje uelastycznienia (,rozciagania”) terminu i zachęcają do używania słowa biblioteka dla określenia specyficznych oczekiwań odbiorcy co do korzystania z przekazów gromadzonych bądź nawigowanych przez bibliotekę. Myślenie o bibliotece $\mathrm{w}$ tym duchu łączy się z nowoczesnym pojmowaniem idei i filozofii tworzenia uniwersalnego zbioru w postaci materialnej i/lub cyfrowej, który docelowo pomieści całą spuściznę myśli ludzkiej, co zreszta od wielu lat akcentował m.in. angielski uczony i praktyk bibliotekarstwa Maurice B. Line (zm. 2010). Według profesora systemy biblioteczne przełomu XX i XXI stulecia polegają na zarządzaniu informacją na potrzeby ludzi. Chodzi o gotowość bibliotek do nowych zadań, przewidywalność przyszłych oczekiwań klientów, by móc sprostać potencjalnym zapytaniom, czyli zaspokoić głód wiedzy i to nie tylko w sensie edukacyjnym ${ }^{10}$. Takie, zdawałoby się oczywiste, gdyż funkcjonalne rozumienie biblioteki rozmija się jednak z istniejącym równolegle od wieków obiegowym myśleniem o tej przestrzeni jako miejscu przystosowanym do przechowywania i udostępniania zbiorów (gmach, pokój, szafa, regały etc.) z obecnym (lub nie) człowiekiem (najczęściej bibliotekarka) w roli „strażnika” zdeponowanych tam dzieł. Podobny obraz biblioteki - czytelni (styl wieży, pałacu, domu) bądź biblioteki - przestrzeni magazynowej (np. na kształt labiryntu) wykreowało kino.

Twórcy filmowi preferują obraz bibliotek klasycznych, budowanych przez stulecia i służących kolejnym pokoleniom ludzkości. Przedstawiaja je jako skarbnice intelektualnego dorobku ludzkości, głównie w postaci

${ }^{8}$ M. Hopfinger, Literatura i media. Po 1989 roku, Warszawa 2010, s. 95.

9 Tamże.

${ }^{10}$ Zob. M.B. Line, Library Management Styles and Structures, a Need to Rethink?, „Journal of Librarianship and Information Science", London 1991, vol. 23, nr 2, s. 97-104. 
utrwalonych materialnie dokumentów drukowanych (czasami pisanych ręcznie), które są chronione i reglamentowane, a zatem dostęp do nich bywa utrudniony. Rzadko dostrzegają zmiany, jakie się dokonały w książnicach w ostatnim dwudziestoleciu, albo po prostu nie chca ich zauważać, gdyż nie pasują do budowanego przekazu filmowego. Kino jest w tym względzie bezlitosne, gdyż nawet jeśli widzimy w filmie piękne i nowoczesne wnętrze biblioteki, to i tak w charakterze „twierdzy i raju”"11, a nie tzw. „trzeciego miejsca", czyli spersonalizowanego i otwartego na potrzeby społeczeństwa XXI wieku centrum kultury, nauki i relaksu ${ }^{12}$.

Współczesna biblioteka strukturą przypomina miasto lub choćby galerię handlową z przejrzystymi ciagami komunikacyjnymi, zróżnicowaniem przestrzeni na strefy otwarte i zamknięte. Jej układ jest dostosowany do potrzeb tak użytkowników o zindywidualizowanych wymaganiach, jak i klientów działających wspólnie. W przeciwieństwie do książnic sprzed wieków oraz tych z I połowy XX stulecia, jej wnętrze nie ma w sobie żadnych tajemnic czy łamigłówek, które by komplikowały dostęp. Przeciwnie, zostały tak zaprojektowane, aby zachęcać do odwiedzin i ograniczać, jak to tylko możliwe, mechanizmy utrudniające korzystanie ze zbiorów.

Dzisiaj dobrze zorganizowana i zarządzana biblioteka to instytucja, która jest czuła na wciąż rosnące wymagania i zmieniające się potrzeby użytkowników, notabene częściej nazywanych klientami niż czytelnikami. W pewnym sensie już ma to miejsce, a niebawem norma będzie niezawodność, szybkość i różnorodność świadczenia zindywidualizowanych usług (i przestrzeganie wskaźników zadowolenia odbiorców bibliotek). Być może już najważniejszy jest szybki i niezawodny transfer zamówionych przez klienta biblioteki danych, gdyż, jak przekonywał ponad 10 lat temu Manuel Castells, „Wszystko, co ma znaczenie, to wymiana impulsów w Sieci” ${ }^{13}$.

${ }^{11}$ Powołuję się na sformułowanie Krzysztofa Łęckiego. Zob. tegoż, Biblioteka - twierdza i raj, [w:] Światta biblioteki otwartej..., s. 62-71.

${ }^{12}$ Cytat pochodzi z artykułu Dagmary Roszkowskiej pt. Biblioteka „trzecim miejscem”?, w którym autorka poszukuje nowej funkcji dla biblioteki XXI wieku. Najbliższa jej jest koncepcja „trzeciego miejsca” Raya Oldenburga rozumiana jako publiczny lokal, gdzie stale, dobrowolnie przychodzą ludzie traktujący go jako dopełnienie przestrzeni domowej i sfery pracy. W klasycznej definicji atrakcyjność owego „trzeciego miejsca” polega na tym, że służy relaksacji i socjalizacji; w przypadku, gdy ma nim być biblioteka, chodzi również o potencjał stymulujący wszechstronny rozwój jednostki i/lub grupy w komfortowych warunkach. Zob.: „Warsztaty Bibliotekarskie” 2016, nr 2 (46), <http://warsztatybibliotekarskie.pedagogiczna. edu.pl/nr-22015-46/biblioteka-trzecim-miejscem/> [dostęp: 20.08.2019]. Por. również: J. Jędrych, Ray Oldenburg i jego teoria trzeciego miejsca, „Warsztaty Bibliotekarskie” 2015, nr 1 (45), <http://warsztatybibliotekarskie.pedagogiczna.edu.pl/nr-12015-45/ray-oldenburg-i-jego-teoria-trzeciego-miejsca/> [dostęp: 20.08.2019].

${ }^{13}$ M. Castells, Wszystko, co ma znaczenie, to wymiana impulsów w Sieci, rozm. przepr. C. Barney, „Magazyn Sztuki” 2000, nr 24, s. 104. 
Sceny biblioteczne obecne w filmach, choć zwykle nastrojowe, intrygujące bądź tajemnicze oraz interesujące estetycznie i ważne dla fabuły, jakby nie oddają dystynktywności tego miejsca, naturalnego przecież otoczenia człowieka światłego i poszukującego. Nieco lepiej wygląda sytuacja bibliotek z perspektywy nielicznych bohaterów filmowych. Ze strzępków odgrywanych na oczach widzów ludzkich losów kręconych w bibliotecznych wnętrzach, łatwo odgadnać ich zamiłowanie do książek i traktujących książnice jako strefy szczególne, w których można się schronić przed innymi, niezbędne do funkcjonowania, psychicznej regeneracji ${ }^{14}$.

Odwrotnym przykładem, czyli początkiem końca pięknej miłości, jest scena erotyczna w domowej bibliotece ukazana w brytyjsko-francuskim melodramacie z 2007 roku Pokuta (Atonement) ${ }^{15}$. Reżyser filmu Joe Wright uczynił z trwającej dosłownie chwilę sceny zbliżenia między Cecillią Tallis a Robbiem Turnerem najważniejszy ekwiwalent stanów uczuciowych bohaterów, które zdeterminują ich losy. Przestrzeń biblioteki została niemal ukryta przed wzrokiem tak bohaterów filmowych, jak i widzów przed ekranem, a jednocześnie spersonalizowana i mentalnie wielokrotnie rekonstruowana w różnych konfiguracjach. Przypadkowym świadkiem tego zdarzenia była Briony - trzynastoletnia siostra Cecilli. Można się zastanawiać, co właściwie zobaczyła dziewczynka? Z pozycji widza przed ekranem widać bowiem niewiele. Obraz biblioteki jest nieostry i ciemny, tak więc bardziej oddziałuje wyobraźnia wzmocniona sferą dochodzących dźwięków. Można się tylko domyślać, że takie właśnie były doznania Briony dochodzące z wnętrza pomieszczenia. Pewnie nie do końca uświadomione zdarzenie w bibliotece, pobudzone intuicją i wyobraźnia, wzbudziło w niej zazdrość i złość na Robbiego. Okazało się jednak kluczowym dla tragicznego w skutkach dalszego ciagu fabuły. Czując się urażona przez Robbiego, Briony skłamała, że to on był sprawcą gwałtu dokonanego chwilę później na Loli - córce drugiej swo-

${ }^{14} \mathrm{~W}$ dokumentalnym filmie Kto (1975) widzowi udziela się wizja przeżyć i doświadczeń towarzyszących jego twórcom, tj. Józefowi Gębskiemu i Antoniemu Halorowi. Związana jest z książkami, które widzimy wszędzie: w zajmujących cała ścianę dużego pokoju w prywatnym mieszkaniu bibliotece, w różnych innych miejscach bytowania człowieka, aż wreszcie przeznaczonych na makulaturę. Obraz natłoku książek paradoksalnie potęguje nasze zrozumienie dla ich wartości. Pomiędzy widzem a realizatorami tworzy się mentalna przestrzeń empatii wobec osób, dla których lektura jest oczywistością. Dla twórców nie ma znaczenia fakt, że odchodzimy ze świata z całym bagażem zdobytej wiedzy, gdyż ta jest nieprzekazywalna. Czytelnikom nie przeszkadza, że umieramy razem z „naszymi” książkami. Dzielę się refleksja, jaką wzbudził we mnie ten enigmatyczny w formie i treści króciutki film, ubolewając, że podobnych w kinie jest niewiele.

${ }^{15}$ Jest to ekranizacja dzieła brytyjskiego pisarza Iana McEwana pod tym samym tytułem, które w 2001 roku było nominowane do nagrody za najlepszą anglojęzyczną powieść. Według rankingu magazynu „Time” Pokutę ogłoszono najlepszym dziełem tegoż roku i tym samym została umieszczona na liście stu największych powieści w historii. 
jej siostry Emily. Oskarżenie o gwałt zaważyło na rozdzieleniu na zawsze Cecilli i Robbiego, natomiast Briony nigdy sobie nie wybaczyła haniebnej postawy wobec drogich sobie osób ${ }^{16}$. Przypadek sprawił, że biblioteka w Pokucie, która miała być azylem dla kochanków, strefą intymną i przyjazną dla całej rodziny, stała się miejscem niszczącym, przeklętym. Można przyjać za Janem Mukařovskim, że w tym obrazie „koegzystują dwie linie znaczeniowe: przestrzeń i fabuła. Ich wzajemny stosunek jest widoczny bez względu na to, czy reżyser go uwzględnia, czy też nie"17. Idąc tym tropem należałoby dodać, że „tok fabularny staje się więc podstawowym ciagiem znaczeniowym, podczas gdy tok przestrzenny stanowi element dyferencjacyjny i w konsekwencji przestrzeń jest wyznaczona przez fabułę"18.

Biblioteka w obiegowym pojęciu kojarzy się z instytucją publiczną, do której każdy może wejść, skorzystać na miejscu lub wypożyczyć - niezbędna z jakichś powodów - książkę. Jest to w zbiorowej wyobraźni miejsce szczególne, w sposób uporządkowany wypełnione ścianami regałów z książkami (i innymi przekazami tekstowymi, wizualnymi i audiowizualnymi). Jest to też optymalne terytorium do samodzielnej nauki, przestrzeń ciszy, a komunikacja między bibliotekarzami i użytkownikami sprowadza się do mówienia szeptem. W naszym kraju, niestety, biblioteka od kilkudziesięciu lat bywa postrzegana przez tzw. ogół społeczeństwa obojętnie lub pejoratywnie jako instytucja, gdzie zatrzymał się czas i powolnie (wolniej niż gdzie indziej) dochodzi do „rozmowy z cyfrowym cieniem” 19 .

Gwoli sprawiedliwości należy dodać, że ów daleki od nowoczesności portret biblioteki z czasów PRL, pełnej obłożonych „w szary papier” ksiażek, to przeszłość. Przynajmniej od ok. 20 lat biblioteki polskie przechodza korzystne metamorfozy, upodobniając się do placówek w innych częściach świata. Najbardziej widoczne przeobrażenia dokonały się w książnicach akademickich. W większości są to nowe i wysmakowane architektonicznie budynki z wolnym dostępem do zbiorów ${ }^{20}$. Po przyłączeniu Polski do Unii Europejskiej szansę rozwoju dostały biblioteki publiczne i szkolne, które do dnia dzisiejszego sporadycznie spełniają standardy nowoczesnej edukacji, nie wspominając o funkcjonalności, dbałości o design.

${ }^{16}$ Zob. J. Szczerba, Zobaczyła, pomyślała, skłamała, „Gazeta Wyborcza” 2008, nr 32, s. 17.

17 J. Mukařovský, W stronę estetyki filmu, [w:] Estetyka i film, red. A. Helman, Warszawa 1972, s. 114. Cyt. za: T. Miczka, E. Ostrowska, Przestrzeń, [w:] Stownik pojęć filmowych, t. 9: Ruch, czas, przestrzeń, montaż, Katowice 1998, s. 109.

18 T. Miczka, E. Ostrowska, dz. cyt., s. 109.

${ }^{19}$ Dla podkreślenia wagi rzeczywistości wirtualnej rozumianej jako medium służące komunikacji użyłam tytułu książki Piotra Sitarskiego. Zob. P. Sitarski, Rozmowa z cyfrowym cieniem. Rzeczywistość wirtualna jako przedmiot zainteresowania humanisty, Kraków 2002.

${ }^{20}$ Zob. m.in.: B. Główka, Nowe w bibliotekarstwie akademickim - widziane przez biblio-

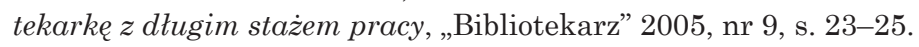


Biblioteki rozumiane jako budynki, wnętrza przechowujace księgozbiór (i pozostałe typy dokumentów), podobnie jak inne instytucje użyteczności publicznej, epizodycznie były i sa wykorzystywane w filmach fabularnych i animowanych oraz w serialach telewizyjnych. Pokusa dla reżysera, aby włączyć do filmu scenę(y) biblioteczną(e) jest najczęściej strona wizualna wybranego w tym celu obiektu. Bywa, że biblioteki stanowią fascynujacca architektonicznie lokalizację filmowa, w której można zainscenizować różne sytuacje na użytek fabuły filmu jako znak rozpoznawczy miejsca lub wyjątkowe tło.

Do tej pory $\mathrm{w}$ historii kinematografii pierwszeństwo mają biblioteki amerykańskie z New York Public Library na szczycie rankingu ${ }^{21}$. Zdarza się, że umieszczenie konkretnej biblioteki w filmie ma charakter li tylko promocyjny lub stanowi akcent dekoracyjny. Jednym słowem, twórcom filmowym zwykle nie chodzi o temat powiązany z czytelnictwem, ale o wyjątkowe (z różnych powodów) miejsce, do którego łatwo można wprowadzić bohaterów (i ekipę filmowa). Biblioteka jako symbol wolności słowa i tolerancji, mądrości społeczeństwa, trwałości kultury czy jej kruchości wiele razy podlegała w filmie spektakularnemu niszczeniu lub odrodzeniu. W Wehikule czasu (The Time Machine, 2002; reż. Simon Wells) za osiemset lat w przyszłość książki zamieniły się w pył, ale cyfrowy system informacyjny nadal działa, tak więc można korzystać z idealnie odwzorowujących oryginały plików-obrazów, a pomoca służą awatary bibliotekarzy. W katastroficznym filmie Pojutrze (The Day After Tomorrow, 2004; reż. Roland Emmerich) Nowojorska Biblioteka Publiczna jest ostatnia deską ratunku w czasie apokalipsy przed nową epoką lodowcową. Garstka bohaterów przeżyje dzięki schronieniu się w bibliotece, a że „cel uświęca środki” - grzeją się, paląc książki w wielkim

${ }^{21}$ Sceny kręcone w Nowojorskiej Bibliotece Publicznej lub na tle fasady budynku znalazły się m.in. w następujących filmach: Ulica szaleństw (1933, reż. Lloyd Bacon), Portret Jennie (1948, reż. William Dieterle), Kradzież na South Street (1953, reż. Samuel Fuller), Śniadanie u Tiffany'ego (1961, reż. Blake Edwards), Dwoje na huśtawce (1962, reż. Robert Wise), Jesteś już mężczyzna (1966, reż. Francis Ford Coppola), Opętanie Joela Delaneya (1972, reż. Waris Hussein), Sieć (1976, reż. Sidney Lumet), Czarnoksiężnik z krainy Oz (1978, reż. Sidney Lumet), Rozdziat drugi (1979, reż. Robert Moore), Ucieczka z Nowego Jorku (1981, reż. John Carpenter), Wybór Zofii (1982, reż. Alan Jay Pakula), Pogromcy duchów (1984, reż. Ivan Reitman), Honor Prizzich (1985, reż. John Huston), Nie do taktu (1986, reż. Michael Dinner), Odnaleźć siebie (1991, reż. Mike Nichols), Maż idealny (1997, reż. Glenn Gordon Caron), Afera Thomasa Crowna (1999, reż. John McTiernan), Bez pamięci (2001, reż. Mark Waters), Spider-Man (2002, reż. Sam Raimi), Dziś 13, jutro 30 (2004, reż. Gary Winick), Na skróty do szczęścia (2004, reż. Alec Baldwin), Pojutrze (2004, reż. Roland Emmerich), Niepewność (2008, reż. Scott McGehee, David Siegel), Władcy umysłów (2011, reż. George Nolfi), Artur (2011, reż. Jason Winer), We'll Take Manhattan (2012, reż. John McKay), Zimowa opowieść (2014, reż. Akiva Goldsman). Ponadto Carrie i Big z seriali Seks w wielkim mieście (2008) planowali ślub w budynku ww. biblioteki. 
kominku. Spaleniu ulega biblioteka z amerykańskiego filmu Storm Center z 1956 roku (reż. Daniel Taradash), a bibliotekarka chroniąca intelektualna wolność i prawo do czytania bez cenzury jest napiętnowana przez lokalną społeczność i zostaje zwolniona ${ }^{22}$.

Wiele gmachów bibliotecznych promieniuje na otoczenie i nadaje mu wyraz szczególnych miejsc. Ruchy kamery, jej punkty i katy widzenia dodatkowo mogą wzmacniać efekt ekranowy fasady książnicy, prowadzących do środka reprezentacyjnych schodów, uwydatnić urodę detali architektonicznych i wyposażenia. Spektakularnym przykładem udziału widzów w swoistej uczcie intelektualnej i wzrokowej z biblioteką ogniskująca bohaterów może być film Siedem (Seven) z 1995 roku w reżyserii Davida Finchera. Biblioteka jest nie tylko osią narracji, ale „gra” cała bryła, stylowymi wnętrzami, zielonym kolorem czytelnianych lamp, aurą zacisznych miejsc, tajemniczymi przejściami między regałami i sącząca się w tle muzyką Bacha. Scala wizualnie i mentalnie najważniejsze według André Gaudreaulta elementy narracji filmowej, czyli narratora, czas, przestrzeń i punkt widzenia. W przypadku filmu Seven przestrzeń biblioteczna (biblioteka idealna, monumentalna, piękna i „z duszą) okazała się nie do zastapienia, zarówno ze względu na odpowiednią rekonstrukcję fabuły, jak i estetykę miejsca idealnie dopasowanego do emocji, które wzbudza dzieło Finchera. Widz zresztą otrzymuje równocześnie wiele przekazów na temat ukazanej $\mathrm{w}$ filmie przestrzeni bibliotecznej. Prezentowana biblioteka jest nie tylko rozpoznawalnym punktem ma mapie wielkiego amerykańskiego miasta, ale też ważną instytucją o charakterze kulturalnym oraz miejscem nauki i kontemplacji mieszkańców, w tym miejscowych detektywów. Dla tych ostatnich to również przystań na odpoczynek i szukanie rozwiązań najbardziej skomplikowanych kryminalnych zagadek. Poszukiwany przez Somerseta (Morgan Freeman) i Millsa (Brad Pitt) morderca swoje zaburzone „myśli przelewa na papier" ('sledczy mają dostęp do setek notesów). Prowadzący dochodzenie analizują dane i porównują z informacjami z książek, z których mógł czerpać instrukcje morderca, jak w sposób wyrafinowany dokonywać bestialskich zbrodni. Biblioteka służy reżyserowi do scenografii, konstrukcji ujęć, budowania napięcia i montażu, czego rezultatem jest holistyczna całość. Dla detektywów książnica jest impulsem do własnych rozważań, rozwoju umiejętności analitycznych, szukania sensu życia i zmysłowego

${ }^{22} \mathrm{~W}$ roli filmowej bibliotekarki, której zarzucono propagowanie idei komunistycznych i indoktrynowanie czytelników wystapiła Bette Davis. Postać ta była wzorowana na losach bibliotekarki z Bartlesville w stanie Oklahoma - Ruth Winifred Brown, która w 1950 roku straciła pracę z powodu działań desegregacyjnych. Zob. L.S. Robbins, The Dismissal of Miss Ruth Brown: Civil Rights, Censorship, and the American Library, University of Oklahoma Press 2001. 
odbierania jego piękna. Książki naprowadzają na właściwy ślad. Podglądamy Somerseta, jak studiuje je nocami w bibliotece, a potem przekazuje wraz z notatkami Millsowi. Pierwszym tropem jest Boska Komedia Dantego Alighieri, w dalszej kolejności Wspótczesne śledztwo w sprawie zabójstwa $z$ zimna krwia, Mein Kampf, dzieła Markiza de Sade, Suma teologiczna św. Tomasza z Akwinu, z których morderca utwierdza się, że siedem grzechów głównych rodzi się „w głowie”...

Dawne książnice bywają też reprezentacyjnymi przestrzeniami w filmach historycznych (np. biblioteka w opactwie Benedyktynów w północnych Włoszech, w projekcie Der Name der Rose, czyli Imię róży z 1986 roku w reż. Jeana-Jacques'a Annauda według powieści Umberto Eco), kostiumowych, a nawet w melodramatach (np. Uczciwa kurtyzana / Dangerous Beauty, 1998; reż. Marshall Herskovitz).

Bezpretensjonalnymi lokalizacjami, jakby naturalnie pasujacymi do fabuły wielu filmów obyczajowych oraz grozy są też obszerne wnętrza wciąż działających, ale nieremontowanych od dawien dawna bibliotek prowincjonalnych. Sa zwykle zagracone, niedoświetlone, ponure. Mroczne tło z wnętrzem tradycyjnej biblioteki, z królująca tam stateczną bibliotekarką wymyślił w powieści To (It) Stephen King - amerykański autor i scenarzysta filmów grozy. Jak zauważyła Marta Górna, to właśnie Stephen King „popsuł klaunom reputację i pokazał niewinną Amerykę lat pięćdziesiątych jako siedlisko zła" ${ }^{23}$. W filmie $I t$, powstałym według jego powieści, widzimy, że spokojną mieściną amerykańską wstrząsnęła seria morderstw popełnionych na dzieciach. Z potworem, ukazującym się w postaci klauna, nie może sobie poradzić grupa bliskich sobie ludzi. Trzydzieści lat później ci sami bohaterowie po raz kolejny muszą się zmierzyć z dramatem z przeszłości i stawić czoła okrucieństwu sytuacji. Wnętrze biblioteki użyte przez reżysera To/ It Andresa Muschietti okazało się wręcz fenomenalne, aby budować napięcie niepokoju i strachu. Rzędy ciasno ustawionych regałów, korytarze, schody, przesmyki, zakamarki, piwnice, pudła to otoczenie przestronnej czytelni, ale też przestrzeń, w której łatwo się zagubić, zniknąć. Tak właśnie jest $\mathrm{w}$ horrorze nakręconym na podstawie It Stephena Kinga: w bibliotece panuje cisza, choć w czytelni siedzi parę osób, w tym przyjazna wszystkim bibliotekarka. Pozornie przytulne, przyjazne, ale mogace obudzić ekscytujący przestrach lokum, na widok przemieszczającego się czerwonego balonika i dziecięcego głosu, paraliżuje filmową ofiarę, ale też przeraża i hipnotyzuje widzów przed ekranem.

Niekończące się rzędy identycznych regałów wypełnionych książkami i wasskie przejścia między nimi w wielu filmach zostały wykorzystane jako

${ }^{23}$ M. Górna, To King popsuł klaunom reputację, „Gazeta Wyborcza” 2019, nr 211, s. 15. 
idealne miejsce sprzyjające odosobnieniu. Są podobnie kadrowane, tak że widoczna jest cała majestatyczność biblioteki, a w niej zanurzeni w swoich prywatnych światach ludzie. W przypadku minimalistycznej i pięknej biblioteki pokazanej w City of Angels (polski tytuł: Miasto aniotów, 1998, w reżyserii Brada Silberlinga według scenariusza Wima Wendersa) chodzi o niezwykłą rozmowę pożegnalną pomiędzy głównymi bohaterami: lekarką Maggie Rice (w tej roli Meg Ryan) i zakochanym w niej aniołem Sethem (Nicolas Cage).

\section{Bibliotekarki i... bibliotekarze}

Pewien niedosyt pozostawia analiza filmowych figur bibliotekarek i bibliotekarzy. Najczęściej mamy do czynienia z ich cielesnością jako przestrzenią fotograficzną wykorzystywaną marginalnie w bliskich planach dla uporządkowania i uwiarygodnienia akcji filmu. Tym bardziej należy docenić amerykański dramat Storm Center z 1956 roku w reżyserii Daniela Taradasha, w którym bibliotekarka Alicia Hull, obrończyni wolności praw człowieka, za wszelką cenę broni apolityczności i cenzurowania swojej książnicy. Widzowie pokochali za tę rolę Bette Davis, która z pewnością przysporzyła popularności filmowi i w wielkim stylu przywróciła pamięć o wydarzeniu, które naprawdę miało miejsce.

Dla scenarzystów filmowych atrakcyjny bywa sam zawód bibliotekarza (przeważnie bibliotekarki), w którym obsadza się drugoplanowe postacie (zwykle „ofiary losu”). Tylko sporadycznie są to role wiodące ${ }^{24}$. Poza Alicia Hull adeptki szkół bibliotekarskich chętnie utożsamiają się z takimi bohaterkami „po fachu”, jak: Gloria Mundy z Nieczystego zagrania / Foul Play (1978, rola Goldie Hawn) czy zjawiskowa pod względem urody i intelektu Evelyn Carnahan (rola Rachel Weisz w Mumii z 1999 roku). Analiza aktywności internetowych fanów serialu Lemony Snicket: Seria niefortunnych zdarzeń (Netflix, od 13 stycznia 2017 roku) poświadcza wyjątkowa popularność Sary Rue, która wcieliła się w postać Olivii Caliban - bibliotekarki i wolontariuszki z „Akademii Antypatii”, która na naszych oczach zmienia się z niepozornej dziewczyny w zabawna, pełną dowcipu i seksapilu kobietę w czerwonych szpilkach, brawurowo przemieszczającą się po korytarzach

${ }^{24}$ Bibliotekarze wielokrotnie wyrażali swoje zastrzeżenia na temat jednostronnego i rozmijającego się z faktami oglądu biblioteki i ich pracy w tekstach literackich, filmowych, medialnych, ale bez większego rezultatu. Literatura, teatr i film sporadycznie przyjmuja ich punkt widzenia, że czasami ma się wrażenie, iż to jakaś zmowa i przekora autorów, aby z niemal każdej bibliotekarki zrobić przemądrzała, przewrażliwioną na swoim punkcie jędzę, bądź nijaka, bojącą się własnego cienia starą pannę. 
książnicy wózkiem służącym do transportu książek. Ponadto po mieście porusza się żółtym garbusem VW, bibliotekę otwiera na 10 minut dziennie, gdyż (cyt. film:) „dłuższe czytanie może zaszkodzić jej podopiecznym”, jej ulubiona powieścia jest Zabić drozda Harper Lee (który to tytuł jedna z uczennic zrozumie dosłownie), a życiowym mottem jest cytat (jakby z $\mathrm{Mi}$ strza i Małgorzaty Bułhakowa): „Każdy dostaje to, czego chce!”25. Jest to typowa gwiazdka popkulturowa, która zapewne szybko zostanie zastapiona inną serialowa „twarzą, ale - póki co - bibliotekarka Olivia Caliban zyskuje sympatię na Facebooku, Instagramie, Pintereście, w blogosferze. Moja uwagę przykuły liczne karykatury, rysunki, kolaże i stylizacje Olivii, jak również polski blog pod intrygującą nazwa „Biblioteka Edgara” (z pewnościa o Edgara Allana Poe chodziło). Jego_autorka zamieściła szczegółową analizę konotacji związanych z bohaterka, której fragment pozwolę sobie zacytować:

Jeszcze garść ciekawostek. Nazwisko Caliban pochodzi, jak przypuszczam, ze sztuki Williama Szekspira Burza. Pojawiający się w niej Kaliban był dzikusem, którego wzią pod swoje skrzydła i między innymi nauczył czytać Prospero, czarodziej-rozbitek. Na dodatek Kaliban był synem wiedźmy Sykoraks, a Olivia Caliban, w jednej z odsłon serii, dociera do wesołego miasteczka o nazwie Gabinet Caligariego (również nieprzypadkowa nazwa, ale to już pomińmy, wielbiciele starych filmów zaśmieją się z żartu, dociekliwi mogą sobie sprawdzić), gdzie wciela się w wiedźmę Madame Lulu. Co ciekawe, w oryginalnej serii Olivia Caliban nie była bibliotekarka i nie pracowała w Akademii Antypatii. Spotykamy ją tylko w tomie Krwiożerczy Karnawat, gdzie na polecenie WZS wolontariuszka wciela się w Madame Lulu.

Tym samym Olivia Caliban dołącza do naszej galerii popkulturowych bibliotekarek, zajmując miejsce obok Sadie, Aurory Teagarden i Celestyny Pajączek ${ }^{26}$.

Poza tymi zupełnie wyjatkowymi w historii kina postaciami bibliotekarek, w większości filmów nadal przeważa stereotypowy obraz kobiety wykonującej ten zawód: mało atrakcyjnej, w okularach krótkowidza, w niemodnym stroju, zadufanej w sobie, nieprzystępnej, niemiłej dla czytelników. Wcale nierzadko bibliotekarki (czasami bibliotekarze również) w filmach fabularnych, a zwłaszcza w kreskówkach, sa parodiowane, przedstawiane jako osoby myślące i zachowujące się daleko inaczej niż zwykli ludzie. Bywa, że wzbudzają szacunek, jak Madame Irma Pince - bibliotekarka pracująca w Szkole Magii i Czarodziejstwa w Hogwarcie (Harry Potter and the Philo-

${ }^{25}$ Chodzi o drugi sezon adaptacji cyklu powieści Daniela Handlera (ukrywającego się pod pseudonimem Lemony Snicket) pt. Lemony Snicket: Seria niefortunnych zdarzeń (Netflix, od 13.01.2017). I tym razem - jak pisze Aneta Kyzioł - to: „Podlana sosem ironii i angielskiej satyry mieszanka przygodówki i kryminału”. Tejże, Sierotki kontra opiekun, „Polityka” 2017, nr 2, s. 67.

${ }^{26}$ Zob. Post Bibliotekarka Olivia Caliban, blog „Biblioteka Edgara”, <http://biblioteka-edgara.blogspot.com/2018/08/bibliotekarka-olivia-caliban.html> [dostęp: 20.08.2019]. 
sopher's Stone w reż. Chrisa Columbusa, 2001), bohaterka drugoplanowa (którą zagrała Sally Mortemore), ale jakże wyrazista. Na każdym egzemplarzu bibliotecznym było jej ostrzeżenie, które stanowi swoiste clou marzenia Irmy Pince, by tak właśnie postępowali wszyscy bywalcy książnicy:

\section{Ostrzeżenie:}

Jeśli tę książkę podrzesz, porwiesz, postrzępisz, pogniesz, pozaginasz, pomażesz, pobrudzisz, poplamisz, poślinisz czy popaćkasz, jeśli ją ciśniesz lub upuścisz albo w jakikolwiek inny sposób zbezcześcisz, uszkodzisz czy potraktujesz bez należytego szacunku, możesz się spodziewać najbardziej surowych kar, jakimi dysponuję. Irma Pince, bibliotekarka Hogwartu

Filmową bibliotekarką szkolną (czytaj: „skostniała starą panną) była niejaka Miss Rowling (w tej roli Carol Kane) z filmu Zgrywus (Big Bully, reż. Steve Miner, 1996). Wcale nie ucieszyła się, gdy po kilkunastu latach od matury odwiedził ją były uczeń David Leary, obecnie sławny pisarz. Widząc ją przy biurku, jakby to było wczoraj, ogarnęło go wzruszenie, więc z potrzeby serca wyznał bibliotekarce, ile dla niego znaczyło to miejsce, i że to tu zrozumiał, jak ważne jest w życiu czytanie. Rowling nie odwzajemniła empatii, ograniczając się do suchego przypomnienia, że nie oddał książki Zielone jajka z szynk ${ }^{27}$ i... „zalega z nią 8862 dni”. W tym przypadku należy zwrócić uwagę na różne relacje, w jakie wchodzą bohaterowie filmu z czasoprzestrzenią biblioteki. Dla Davida biblioteka szkolna jest to miejsce, w którym dokonała się inicjacja jego potrzeb czytelniczych, pamiętane jako ponadczasowa wartość. Dla bibliotekarki to wciąż przestrzeń pracy (te same obowiązki, pilnowanie nieznośnych uczniów, którzy nie szanują i nie zwracają książek na czas) i trudno odgadnąć z jej twarzy, czy lubi swój zawód.

W Historiach miłosnych (1997, reż., scenariusz i odtwórca głównych ról Jerzy Stuhr) mamy do czynienia z niewielkim segmentem przestrzeni bibliotecznej, tj. z fragmentem magazynu książek usytuowanym tuż za czytelnia, który jest kluczowy dla czasu i miejsca akcji. Pryncypialna bibliotekarka (gra ją Aleksandra Górska) wchodzi nagle do magazynu książek i jednym ruchem zapala światło, przerywając miłosne tête-à-tête adiunktowi (Stuhr). Adiunkt denerwuje się, gdyż nie jest pewien, czy bibliotekarka zobaczyła również towarzyszącą mu studentkę, a jeżeli tak, to czy doniesie dziekanowi. W każdym razie złowrogo zabrzmiały jej słowa: „Prosiłam, aby nie wchodzić tu bez mojej wiedzy”. Wygląd Górskiej i ton, jakim się zwraca do nieprzestrzegajacego regulaminu korzystania z czytelni Stuhra, nie pozostawia

${ }^{27}$ Chodzi o pełne absurdalnego humoru i lekkości dzieło literatury dziecięcej Green eggs and ham napisane i zilustrowane przez amerykańskiego twórcę Dr. Seussa (właśc. Theodor Seuss Geisel, 1904-1991), wydane w 1960 roku. Książeczka służy dzieciom na całym świecie do nauki języka angielskiego. W Polsce dostępna z równoległym tekstem polskim w przekładzie Stanisława Barańczaka pt. Kto zje zielone jajka sadzone? 
złudzeń, że po takich osobach nie należy się spodziewać zrozumienia. Ze strachu o własna karierę doktor wycofuje się z obiecanej pomocy zakochanej w nim dziewczynie (w tej roli Dominika Ostałowska) w zdaniu egzaminu, a to oznacza dla niej koniec studiowania. Biblioteka w tym przypadku stała się strefą nie tak bezpieczną dla kochanków, jak mogłoby się wydawać, zresztą nie jedyny raz w dziejach filmu.

W odcinku Odnaleźć siebie popularnego serialu telewizyjnego Na dobre $i$ na złe pojawiła się Maja Komorowska, która gra nauczycielkę, z powodu poważnych problemów ze wzrokiem przesuniętą do pracy w bibliotece szkolnej. To ponury, choć ciagle nierzadki przypadek wśród cierpiących na niewydolność strun głosowych lub zwyczajnie starzejących się polonistek, innych filolożek bądź historyczek. Smutne jest to, że tak, jak w przytoczonym odcinku filmu, nauczycielka traktuje ten fakt nie jako nowe i pobudzające do działania wyzwanie, ale degradację zawodowa, natomiast ani ona, ani nikt z dyrekcji i rady pedagogicznej nie traktuje pracy bibliotekarskiej z godnością i nie widzi problemu braku fachowych umiejętności na powierzanym jej stanowisku ${ }^{28}$. Warto dodać, że jeśli chodzi o wizerunek, Komorowska jest „wypisz, wymaluj” klasycznie stereotypowa (mądra, nudna, koczek, okulary, zachowawczy strój etc.). Co ciekawe, biblioteka to dla niej miejsce zesłania, którego nie chce poznać, zaakceptować.

Pejoratywny obraz bibliotekarek wynikający z większości fabuł i kreskówek przełamuja filmiki porno, w których bibliotekarki to atrakcyjne wizualnie kobiety, ale i „pierwsze naiwne”, które z czułością odpowiadają na męskie awanse. Tym bardziej zaskakuje zachowanie bibliotekarki Natalie Parker (w tej roli Elizabeth Shannon) w zabawnej, erotycznie zabarwionej komedii Tomcats (Kocurek, 2001, scen. i reż. Gregory Poirier). Nastawiony na seksualne podboje Michael Delaney (Jerry O'Connell) przymila się do - jak się wydaje słodkiej bibliotekarki, która okaże się bezlitosna „dominą”. W panieńskim pokoju pluszowe maskotki to pułapki ułatwiające sadystyczne praktyki.

Jak widać z powyższych obserwacji, poza wyjątkami brak w kinie światowym (w krajowym jest jeszcze gorzej) przeciwwagi dla bibliotekarek przedstawianych (czy zapamiętanych z autopsji) jako kobiety nieszczególnej urody, rzadko emanujące seksapilem, ale za to wykształcone, porządne, oddane pracy i kochające książki ${ }^{29}$. Na ten temat mamy już sporo analiz, z potężną lista

${ }^{28}$ Zob. serial Na dobre i na złe, Polska 1999; odcinek 95 Odnaleźć siebie, 2002, reż. M. Dejczer.

${ }^{29}$ Zmian w wizerunku biblioteki, bibliotekarzy oraz postrzegania instytucji i przedstawicieli zawodu nie zauważyła m.in. autorka tekstu Absolwent kierunku informacja naukowa i bibliotekoznawstwo Aneta Firlej-Buzon („Książka i Czytelnik” 2005, nr 2, s. 10). Artykuł wywołał burzliwą dyskusję na forach internetowych samych zainteresowanych, z reguły niepodzielających stanowiska Firlej. 
lektur, filmów fabularnych, dokumentalnych, reklamowych, amatorskich, spektakli teatralnych, programów kabaretowych, piosenek z biblioteka, bibliotekarka/bibliotekarzem w roli drugo-, a czasami pierwszoplanowej ${ }^{30}$.

W kwietniu 2011 roku w roli bibliotekarki Wandy Wilczyńskiej miała się znaleźć w serialu Na Wspólnej Magdalena Wójcik. Polskie bibliotekarki trzymały kciuki za rozwój wypadków. Oto pojawiła się w scenariuszu ulubionego filmu nowa twarz polskiej bibliotekarki: ,jak z obrazka”, dynamiczna, kreatywna, z pasją realizująca się w zawodzie. W „EBIB” ${ }^{11}$ sa wpisy typu: „Tylko niech to będzie normalna bibliotekarka, a nie przyjęty «stereotyp» kok, okulary, golfik, spódniczka w kratkę, aha i niech ma męża, a nie żeby była stara, zahukaną panna, której na sercu leży tylko to, że ludzie książek nie czytają. Przeciw okularom nic nie mam - sama je noszę..., ale przeważnie bibliotekarka jest pokazywana, jak wyżej opisałam - i na dodatek zawsze ma zacięty wyraz twarzy. Mówię NIE! takiemu wizerunkowi. Ale cała nadzieja w pani Magdzie Wójcik - przepięknej kobiecie! Głęboko wierzę, że jej bibliotekarka będzie taka, jak większość bibliotekarek w Polsce - nieróżniąca się niczym od przedstawicielek innych, szanowanych zawodów" ${ }^{32}$. Niestety, klika minut później Bana zamieściła kolejny wpis potwierdzający rozczarowanie z decyzji twórców co do stroju bibliotekarki: „Przepraszam, że piszę post za swoim postem. Właśnie weszłam na stronę Świata Seriali i niestety sprawdziły się moje najgorsze przeczucia - kok, okulary i ubiór po ciotce. Brak mi słów”33. Faktycznie, Wanda Wilczyńska, „która przeczytała w życiu mnóstwo książek, jest załamana poziomem czytelnictwa w Polsce”, zagrała „bidulkę bibliotekarkę, z którą nikt się nie liczy” tylko w jednym odcinku ${ }^{34}$. $\mathrm{Z}$ podobną do Wandy stereotypową bibliotekarką spotykamy się w 578 odcinku paradokumentalnego serialu TVN Ukryta prawda. Hanna Solińska ma 37 lat, jest absolwentką polonistyki, pracuje w czytelni. Mieszka sama

${ }^{30}$ Zob. m.in. U. Szybowska, Lista przebojów bibliotekarskich hitów na YouTubie, czyli w poszukiwaniu ukrytych skarbów, „EBIB” 2010, nr 3, <http://www.ebib.info/2010/112/a.php?szybowska> [dostęp: 13.08.2019]; J. Wojtczak, Nowe pokolenie bibliotekarzy - oczekiwania a możliwości, [w:] Marketing wewnętrzny i zarzqdzanie zasobami ludzkimi w bibliotece, red. H. Brzezińska-Stec i J. Kudrawiec, Białystok 2009, s. 233-248.

${ }^{31}$ „EBIB”, czyli „Elektroniczny Biuletyn Informacyjny Bibliotekarzy” - strona internetowa przeznaczona dla osób pracujących w bibliotekach czy ośrodkach informacji, studentów i pracowników bibliotekoznawstwa oraz zainteresowanych problematyką bibliotekoznawczą. Dostęp do strony: <http://open.ebib.pl/ojs/index.php/ebib/ index>.

${ }^{32}$ Bana, post, <http://forum.nowyebib.info/pun/viewtopic.php?id=433>; post z 16 kwietnia 2011 roku [dostęp: 20.08.2019].

33 Tamże.

${ }^{34}$ Chodzi o odcinek 1351, <https://player.pl/seriale-online/na-wspolnej-1501-2000-odcinki,5135/odcinek-1531,S01E1531,5547> [dostęp: 20.08.2019]. Ciekawy komentarz nt. współczesnych bibliotekarek czynnych zawodowo zawarła w syntetycznym artykule Mirosława Zygmunt. Zob. tejże, dz. cyt., s. 33. 
z nastoletnią córka, z której wychowaniem sobie nie radzi, choć poświęca jej prawie cały swój czas (nawet - o zgrozo! - odrabia za nia prace domowe). Ma romans z dyrektorem biblioteki, czego córka nie akceptuje. Gdy w chwili szczerości Hanna przyznaje się w domu, że, podobnie jak córka, też miała w szkole oceny dostateczne, mężczyzna wyraża dezaprobatę i zdziwienie, że pomimo to dostała pracę w bibliotece. Cóż, w tym krótkim zdaniu wypowiedzianym przez dyrektora biblioteki, objawił się kolejny raz usankcjonowany w naszej kulturze mit o osobach sprawujących ten zawód: powinny się do niego garnać same prymuski, zawsze i o każdej porze gotowe do wielozadaniowego wysiłku, oczywiście bez wygórowanych oczekiwań płacowych.

Kino światowe niewiele miejsca zostawiło dla mężczyzn pracujących w bibliotekach, chociaż to panowie kształtowali ten zawód do XIX wieku włącznie, scalając profesję mistrza (uczonego) i opiekuna ksiąg. Poza wspomnianym Der Name der Rose i powstałym w 2019 roku włosko-niemieckim serialu kryminalnym w reżyserii Giacomo Battiato (opartych na Imieniu róży Eco), trudno znaleźć równie ciekawy film oddający aurę podskórnego życia bibliotek czasów średnich. Zwłaszcza reżyser Annaud osiagną sukces, jeśli chodzi o dotknięcie tematu mrocznych tajemnic otaczających bibliotekę benedyktyńskiego klasztoru, próbując także pokazać sens i złożoną osobowość spędzających w niej życie zakonnych braci skupionych na przepisywaniu ksiąg przy słabym świetle świec i pracy własnej nad zgłębianiem wiedzy, bynajmniej nie zachęcając do tego zajęcia innych mnichów. Notabene, realistyczne w oglądzie skryptorium i klasztorna biblioteka w filmie z 1986 roku nie należały do dwunastowiecznego klasztoru Cystersów Eberbach, gdzie nakręcono kluczowe sceny, ale było to dzieło scenografów, którzy urządzili te wnętrza w studiu filmowym Cinecittà. Imię róży to jeszcze jeden film, w którym płoną książki, przestaje istnieć chroniona przez wieki biblioteka ${ }^{35}$, ale tym razem zadecydował o tym bibliotekarz. Brat Malachiasz (w tej roli Volker Prechtel) nie mógł się pogodzić, że jego tajemnica została rozwiązana, i to z pomoca przybysza z innego zakonu - franciszkanina Williama z Baskerville (wybitna rola Seana Connery). Trudno oceniać zachowanie bohatera powieści Umberto Eco, jakim był bibliotekarz Malachiasz, gdyż należałoby wziąć pod uwagę różne konteksty, uwzględniające ówczesną kulturę, fakty historyczne, ludzkie namiętności (w tym zachłanność i zazdrość), niemniej trzeba przyznać, że zarówno w czytelnikach, jak i widzach kinowych na długo pozostaje żal, że biblioteka spłonęła, że nie przetrwała do naszych czasów Poetyka Arystotelesa.

${ }^{35}$ Jak wiadomo, w filmie Storm Center biblioteka została podpalona przez chłopca nie zdającego sobie sprawy z nieodwracalności sytuacji. W The Day After Tomorrow książki sa wrzucane do ognia celowo, aby ludzie mogli przetrwać wszechobecny i obezwładniajaccy mróz zwiastujący nową epokę lodowcową. 
A jeśli chodzi o innych mężczyzn zapamiętanych z filmowych ról bibliotekarzy, trzeba podkreślić, że mamy ich coraz więcej. W produkcjach kinowych i telewizyjnych byli wielcy duchem bibliotekarze, jak również tacy, którzy nie zasługują na zaszczyt pracy „w świątyni wiedzy”. Bywaja zatem bohaterowie pozbawieni empatii, nietaktowni, aroganccy, denerwujący etc. Na takiego „typka” trafia przykładowo Zofia Zawistowska - tytułowa postać z filmu Wybór Zofii (Sophie’s Choice w reż. Alana Jaya Pakuli, 1982 ${ }^{36}$, odegrana przez Meryl Streep. Widzimy ją w Nowojorskiej Bibliotece Publicznej w sytuacji bardzo dla niej niekomfortowej. Zofia chce się natychmiast zapoznać ze spuścizną Emily Dickinson, która jest poruszona po wysłuchaniu na zajęciach z literatury jednego z jej wierszy. W tym celu idzie do biblioteki, która okazuje się daleka od ideału. Jest monumentalna, przytłacza anonimowością, obcością i nietolerancją wobec jej osoby ze strony dyżurującego bibliotekarza. Na dodatek Zofia jest w złej kondycji fizycznej i psychicznej, nie wspominając, że słabo (i z „akcentem”) mówi po angielsku. Ten zbieg niefortunnych dla niej okoliczności nie ułatwia wyjścia z opresji. $\mathrm{Na}$ dodatek na wykładzie zanotowała, że chodzi o amerykańskiego poetę Emila Dickensa, a taki przecież nie istniał. Bibliotekarz (w tej roli John Rothman) zwyczajnie nie chce jej pomóc, gdyż wystarczyłoby po prostu wyjaśnić, że przekręciła nazwisko i wskazać miejsce przechowywania książek ulubionej poetki. Należy dodać, że pokazana realistycznie scena filmowa mogłaby być wykorzystana jako modelowa obserwacja zjawiska zwanego w bibliotekarstwie „patologia biblioteczna” ${ }^{37}$.

Negatywny obraz biblioteki i zatrudnionych tam bibliotekarzy (mężczyzn) w sposób zabawny i sarkastyczny przekazuje m.in. duet aktorski David Mitchell i Robert Webb - bohaterowie angielskiego serialu komediowego The Insulting Librarian. Komicy parodiuja chamskie i pogardliwe w stosunku do czytelnika zachowanie bibliotekarza, człowieka pozbawionego hamulców i bezczelnie krytykującego wybór książki dokonany przez czytelniczkę Olivię Colman. W sposób zawoalowany program dotyka problemu tradycjonalistycznych angielskich bibliotek, w których obowiązujące zasady nie przystają do czasów współczesnych, a bibliotekarz rzadko bywa sprzymierzeńcem czytelnika ${ }^{38}$. Notabene, trudno zapomnieć Roberta Webba w roli cynicznego i uszczypliwego bibliotekarza obcesowo traktującego czy-

${ }^{36}$ Film jest adaptacją psychologicznej powieści obyczajowej autorstwa Williama Styrona z 1979 roku. W następnym roku książka otrzymała nagrodę National Book Award for Fiction i znalazła się na liście 100 książek XX wieku według „Le Monde”. Zarówno w powieści, jak i w filmie dwa razy pojawia się wątek poezji Emily Dickinson.

${ }^{37}$ Zob. Z. Żmigrodzki, Patologia biblioteczna, Katowice 1996.

${ }^{38}$ The Insulting Librarian - Mitchell \& Webb; <https://www.youtube.com/watch?v=rqTE-ig7NhY> [dostęp: 20.08.2019]. 
telniczkę tylko dlatego, że zakłóciła mu tzw. święty spokój. Absurdalność sytuacji, w której znalazła się dziewczyna pragnąca zwrócić książę i wypożyczyć kolejna, dowcipnie parodiowana przez aktorów, jest tyleż zabawna, co straszna, tak więc wzbudza w publiczności i śmiech, i konsternację. Podobny przekaz niesie nasz rodzimy spot telewizyjny z udziałem Bohdana Smolenia, który warto w tym miejscu zacytować. Otóż na pytania dzieci czy są książki, bibliotekarz grany przez satyryka, aby się nimi po prostu nie zajmować, odpowiada niezmiennie, że „nie ma!"39.

W The Insulting Librarian mamy też odwrotna sytuację, kiedy to bibliotekarz jest uosobieniem profesjonalizmu i empatii, natomiast klient traktuje czytelnię w sposób daleki od obowiązujących standardów. W odcinku Mitchell and Webb: At the library aktor (Webb) odgrywa rolę niewychowanego „pajaca”, który nic sobie nie robi z powagi książnicy. W ciagu krótkiego czasu na jego stole, oprócz zamówionej książki, pojawiają się różne osobiste rzeczy, w tym saksofon oraz zakupy alkoholowe. Tym razem w rolę bibliotekarza (uprzejmego, cierpliwego, znoszącego ze stoickim spokojem ekscentryczne i zupełnie nie na miejscu zachowanie użytkownika) wcielił się David Mitchell ${ }^{40}$.

Oprócz aktorów, którzy zagrali bibliotecznego safandułę lub aroganta, zwłaszcza we współczesnym kinie pojawił się nowy typ bibliotekarza doceniającego pozytywy tej kobiecej profesji. Chodzi o błyskotliwych mężczyzn o silnej osobowości. Ci „filmowi”, których mam na myśli, sa wręcz zbyt pewni siebie, a na pewno bez kompleksów, że wybrali taki zawód. Decyzję o pracy w bibliotece podjęli świadomie, w zamian za „cenę spokoju” i „mała stabilizację". Takim (jak w każdej kreskówce - przejaskrawionym) typem bibliotekarza jest Szerman z amerykańskiego serialu z 2007 roku w reżyserii Dana Povenmire i Jeffa „Swampy” Marsha pt. Phineas and Ferb (polski tytuł: Fineasz i Ferb ${ }^{41}$ ). Szerman - gwiazda rocka - z powodu niepowodzeń twórczych postanowił „zaszyć się” w bibliotece. Wykoncypował, że jest to miejsce idealne, aby przeżyć bezstresowo, gdyż „nic ciekawego się tu nie dzieje, więc i nic złego nie może człowieka spotkać”. Słychać to doskonale w piosence I Ain't Got Rhythm (Nie czuje rytmu) śpiewanej przez Szermana w duecie z Fineaszem, który nakłaniał muzyka do powrotu na estradę. Podaję polskie tłumaczenie utworu:

${ }^{39}$ P. Marcinkowski, Bibliotekarz. Stereotyp czy wizerunek?, <https://repozytorium.amu. edu.pl/bitstream/10593/117/1/stereotyp.pdf> [dostęp: 21.08.2019].

${ }^{40}$ The Insulting Librarian - Mitchell \& Webb; <https://www.youtube.com/watch?v=XlguQOKkz6g> [dostęp: 20.08.2019].

${ }^{41}$ Wersja polska filmu powstała na zlecenie Disney Character Voices International SDI Media Polska. Reżyserowali: Artur Kaczmarski, Waldemar Modestowicz i Marek Robaczewski. 
Bladego pojęcia nie mam o czym mówicie / Poczucie rytmu mam jak ten blat / - śpiewał Szerman, jednocześnie pieczętując książki „w rytm muzyki” - Spotkało mnie w życiu nieszczęście / Nie chcę, by usłyszał znów o mnie świat / Całkiem miły mam tutaj etacik / I mogę czytać, ile chcę / W koło same babcie, dywan stary i regały / To bibliotekarza życie jest / I refren: Bo już nie czuję rytmu / Już nie czuję rytmu / Już nie czuję rytmu / Nie czuję rytmu... ${ }^{42}$.

Przytoczony epizod „biblioteczny” pochodzi z odcinka Stary, będziemy mieć reaktywację. Muzyka do cytowanej piosenki doczekała się wielu wyróżnień, m.in. zdobyła nominację do nagrody Emmy w 2008 roku ${ }^{43}$.

Nierzadko do obrazu zawodu bibliotekarza nadal nie przystaja tzw. prawdziwi mężczyźni. Nadkomisarz Andrzej Gajewski (gra tę rolę Jerzy Radziwiłowicz; chodzi o serial Glina Władysława Pasikowskiego, który był emitowany w TVP w latach 2003-2008) nie tyle nie może się pogodzić, że odeszła od niego żona, co że porzuciła go - prawdziwego mężczyznę i policjanta - dla... bibliotekarza (w tej roli wystapił Andrzej Dębski). Według Gajewskiego to wręcz nieprzyzwoite realizować się w tak „damskim” zawodzie. „Dlaczego on się nie weźmie za uczciwą robotę?” - rozpacza i jest wręcz zażenowany całą sytuacja, w której już nie ma dla niego miejsca ${ }^{44}$.

Zastanawiające, że również w XXI wieku bibliotekarka, podobnie jak wiele innych kobiecych figur, wciąż bywa filmowana z pozycji represyjnej ${ }^{45}$. Brak też w przestrzeni filmowej portretów bibliotekarek stworzonych przez kobiety „za kamerą” (nadal stanowią ok. 10\% reżyserów), zatem to dalszy ciag narracji wykreowanej przez mężczyzn ${ }^{46}$. Jednak to filmowa bibliotekarka, osobowościowo niezmienna od dziesięcioleci, kobieta w nieokreślonym wieku, o przeciętnej aparycji, noszacca okulary i mało twarzową fryzurę, zdominowała i przekłamała obraz tego wartościowego zawodu. Nawet w kultowym Love Story (1970, reż. Arthur Hiller) bibliotekarki, które zobaczył Oliver (Ryan O’Neal), choć młode, na pierwszy rzut oka wydawały się mało

${ }^{42}$ Muzykę i słowa do polskiej wersji piosenki opracował Krzysztof Pieszak, <http://www. tekstowo.pl/piosenka,fineasz_i_ferb,poczucie_rytmu.html> [dostęp: 21.08.2019].

${ }^{43}$ Piosenka Nie czuje rytmu, <https://www.youtube.com/watch?v=4Dv0SQly5rE > [dostęp: 21.08.2019].

${ }^{44}$ Zob. K. Feusette, Sam jak pies, „Rzeczpospolita” 2004, nr 281, s. A9.

45 Jak konkluduje jednak swoje rozważania w ogóle o przestrzeni filmowej Elżbieta Ostrowska: „Analizy wybranego materiału filmowego ujawniły bowiem, iż przestrzeń, będąc "warunkiem niezbędnym i koniecznym» zaistnienia dzieła filmowego, jest jednocześnie całkowicie «zrepresjonowana» przez dyskurs przezeń konstruowany". E. Ostrowska, Przestrzeń filmowa, Kraków 2000, s. 215.

${ }^{46}$ Zwiastunem zmiany jest ubiegłoroczny Międzynarodowy Festiwal Filmowy w Berlinie, na którym Dyrektor Berlinale podpisał zobowiązanie, które przyjęły już inne imprezy, potwierdzając tym samym, że w 2020 roku w konkursach ma być tyle samo filmów zrealizowanych przez kobiety co przez mężczyzn. B. Hollender, Reżyserki szturmem wzięty europejski festiwal, „Rzeczpospolita” 2019, nr 39, s. 11. 
kobiece i nijakie, tak przynajmniej wynika z powieści, według której ten sam Erich Segal przygotował filmowy scenariusz. A jeżeli już natrafi się w kinie (w telewizji) na atrakcyjną bibliotekarkę, to w większości przypadków oznacza, że musiało jej się w życiu nie ułożyć, skoro pracuje w takiej instytucji (np. Joanna w filmie Patrice'a Leconte'a Bliscy nieznajomi). Dawna partnerka bohatera filmu (grała ją Anne Brochet) miała jednak inne marzenia, niż praca w bibliotece - chciała zostać pisarką. Przygaszona, pogodzona z losem Marian Paroo - bibliotekarka z filmowego musicalu Muzyk (The Music Man, 1962; reż. Morton DaCosta), w którą wcieliła się aktorka Shirley Jones, nie przełamała stereotypu kobiety wykonującej ten zawód z przyjemnością. Jej Marian to niezbyt pewna siebie dziewczyna, która pokazała wprawdzie, że jest sporo warta, ale sama nie do końca w to wierzy.

Stowarzyszonym z filmem przekazem wydają się być coraz bardziej gry komputerowe (internetowe). Celem gry Lary 7 był „podryw” i chęć „zaliczenia” kolejnej dziewczyny. W roli lowelasa na czoło wysuwa się tytułowy Larry Laffer. To mężczyzna mało atrakcyjny fizycznie (jest niski, łysieje, ma brzuch), co bynajmniej nie oznacza, że ma niską samoocenę czy jest nieśmiały wobec kobiet (w polskiej edycji głosu użyczył postaci Jerzy Stuhr). Larry postanawia popłynać w rejs statkiem miłości o nazwie „Babilon”. Dowiaduje się, że na pokładzie trwają zawody, w których główną nagrodą będzie noc z Panią Kapitan! (głosu w polskiej wersji użyczyła Katarzyna Figura). Pragnieniem gracza jest zwycięstwo w konkursie, a co za tym idzie, jak najszybszy odbiór nagrody... Na swej drodze grajaccy spotykają interesujaccych i mniej zajmujących ludzi. W tej drugiej grupie plasuje się bibliotekarka Wiktoria Bibliofilska, ale i tu czekaja graczy niespodzianki. Jak to w grach nacechowanych erotycznie bywa, używany tam język jest dosadny, by nie powiedzieć wulgarny. Tak więc „cięty język to spływający hektolitrami po głośnikach miodzik" - można przeczytać na forum internetowym ${ }^{47}$. Mocnych słów używają wszyscy, ale ku zdziwieniu pozostałych, bibliotekarka również nie unika niecenzuralnych zwrotów. Humor gry balansuje na granicy dobrego i złego smaku. W pewnym momencie wprawdzie Larry (słyszymy głos Stuhra) ocenia bibliotekarkę jako „nieszczególną”, ale po chwili zauważa, że „coś w niej jest”: „Jak Państwo słyszeliście - peroruje zadowolony ze swojego poczucia humoru Larry - komputer Wiktorii Bibliofilskiej - bibliotekarki na statku wycieczkowym - jest tak konserwatywny jak jego właścicielka DOS 2.1 w rzeczy samej".

Dzisiaj aktorki grajace bibliotekarki nadal prezentuja, podobnie jak w literaturze i w starych filmach, dwa, zwykle dopełniające się typy osobowe:

${ }^{47}$ Zob.: 2MAN, Larry 7: Miłość na Fali, <https://www.pcworld.pl/news/Larry-7-Milosc-na-Fali,278692.html> [dostęp: 20.02.2020]. 
w młodości jest to „pierwsza naiwna”, a w dojrzałym życiu zgorzkniała „stara panna”, której „nikt nie chciał za żonę” (sic!). Oczywiście zawsze bywały wyjątki, a w ostatnich latach zaczyna być znacznie ciekawiej w wiadomym względzie. O ile w przeszłości (np. w literaturze) bibliotekarki były pomijane jako nienadające się do roli żony, matki, gospodyni - teraz np. Cezary Pazura (komisarz Waldemar Morawiec, „Nowy”, z filmu Psy II Pasikowskiego) w dialogu z Bogusławem Lindą chwali się, że swoją Mariolkę (porządną dziewczynę) poznał w bibliotece i jest to atut, dobrze świadczy o nich, że bywaja w takich miejscach. Kobieta bibliotekarka, jeśli bywa dzisiaj „,singielka”, to z wyboru. Zwykle jest osobą wykształconą i nieprzystępna, stąd trudno jej znaleźć sobie partnera (podoba się raczej tym o skromniejszym potencjale intelektualnym, którzy z kolei do niej nie pasuja). Niewiele sobie z tego robi, gdyż prowadzi spokojne albo ekscentryczne, zawsze ciekawe i wartościowe życie (nadal czyta pasjami, czyli „połyka” książki - np. Wanda z Na Wspólnej).

Biblioteka we współczesnych filmach to z reguły ciekawa architektonicznie przestrzeń, gdzie można umiejscowić akcję. Bywa również częścią lub tłem opowiadanej w filmie (grze komputerowej) historii. Filmowe biblioteki nadal sa postrzegane jako kapitalne miejsca niezmąconej ciszy, sprzyjające przemyśleniom, stwarzające warunki do intelektualnego wysiłku, ale też relaksu po ciężkim dniu. Z drugiej strony biblioteczna cisza ma znaczenie pejoratywne - czujemy się nieswojo w sztywnej przestrzeni, w której niczego nie wolno: mówić, chodzić, dotykać. Aspekt emocjonalny obsługi użytkowników klasycznej angielskiej książnicy doskonale oddał komik Rowan Sebastian Atkinson, u nas znany jako Jaś Fasola (ang. Mr. Bean). Scena zestresowanego czytelnika w bibliotece, któremu za nic nie udaje się poruszać bezszelestnie, a wręcz przeciwnie - przytrafiają mu się kolejne gafy, na długo pozostanie w pamięci jako przykład patologicznej w swym skostnieniu instytucji.

Ciążenie twórców filmowych ewidentnie zmierza ku wielofunkcyjnej, przyjaznej lokalizacji. Biblioteki na kształt wieży, labiryntu, galerii handlowej z przeznaczeniem kulturotwórczym, czyli biblioteki zadaniowo odpowiadające roli współczesnego miasta - mają zapewnić miejsce do pracy, nauki, kontaktów społecznych, odpoczynku, zakupów (oferować kioski, księgarnie, bufety, miejsca spotkań, galerie wystawowe, sale koncertowe i konferencyjne itp.). Jako instytucja ma zakodowaną kulturowo „strefę zatopienia w ciszy” (w niektórych amerykańskich bibliotekach sa od lat rozkładane na stołach czytelnianych tzw. „pachołki ciszy” - na pomarańczowo świecące szklane trójkąty, zmora dla tych wszystkich, którzy nie są w stanie milczeć przez wiele godzin).

Budynki i wnętrza dzisiejszych bibliotek, z którymi spotykają się kinomani i fani gier komputerowych, w niczym nie przypominaja standardowych książnic z przeszłości, a jeżeli już, to jako efekt scenografii. Są to najczęściej 
nowoczesne projekty architektoniczne, zharmonizowane $\mathrm{z}$ otoczeniem, dostosowane do potrzeb grup docelowych użytkowników. W nawiązaniu do klimatów rodem ze średniowiecza i renesansu, dość powszechnie stosuje się „efekt” klasztornych skryptoriów, bibliotek à la zamki, baszty, wieże, twierdze, by wymienić dekoracje z biblioteką w tle w ekranizacji jednej z części przygód Harry'ego Pottera według powieści Joanne Rowling.

Twórcy najczęściej przedstawiają bibliotekę jako miejsce do pracy, spędzania czasu wolnego przez inteligencję, łączenia się ze światem za pomoca Internetu. Użytkownicy uchwyceni w takim wnętrzu celowo lub przypadkiem czuja się tam dobrze i swobodnie, nie mając wyrzutów, że popełniaja jakieś faux pas (Jaś Fasola), nie tracą wiary, że biblioteki są po to, by służyć tym wszystkim, którzy zaszczycają je swoją obecnością. Szczególną uwagę zwraca funkcjonalność i estetyka wnętrz, by wyróżnić doskonale i luksusowo zaprojektowane miejsca do czytania i inne stanowiska pracy wraz z oprzyrządowaniem (czytniki, monitory, słuchawki, okulary stroboskopowe, hełmy), odpowiednim oświetleniem, dopracowane kolorystycznie. Nie ma wątpliwości, że o „filmowe” przestrzenie biblioteczne zadbali architekci i artyści plastycy. Zreszta, w większości filmów akcję umiejscowiono w prawdziwych bibliotekach. Uwagę przykuwa dbałość o potrzeby użytkowników: są obsługiwani błyskawicznie, rzadko odchodza, nie otrzymawszy poszukiwanego dokumentu, poza tym mogą do woli robić kserokopie, zamawiać zdjęcia, skany itd. (moga pić, jeść, rozmawiać).

Nowy obraz biblioteki/bibliotekarza ma związek ze zmianami cywilizacyjnymi w kierunku organizacji społeczeństwa wiedzy (społeczeństwa Sieci). Spędzanie czasu w bibliotece, miejscu dobrze zaprojektowanym i wyposażonym, dającym poczucie spokoju i komfortu pracy, staje się bezdyskusyjne. Bibliotekarze natomiast coraz bardziej sa świadomi wspomagającej roli wobec „ludzi książki” oraz osób majacych potrzebę i nawyk stałego kontaktu ze słowem drukowanym. Tym bardziej staje się to istotne, że eliminujemy literaturę „na papierze” ze swoich domów. Na zakończenie wywodu dodam, że marzy mi się, aby twórcy filmowi zauważyli biblioteki jako pozytywnie nacechowany snobizm ludzi żyjących w XXI stuleciu. Może powstaną wtedy mądre i artystycznie piękne filmy o istotności trwania tych organizmów, nie do przecenienia „w czasach smartfonów i mediów społecznościowych”. Wprawdzie C. Hart prognozował już ponad dwie dekady temu: „Możliwe, że w przyszłości «domy wiedzy» staną się zbędne, co spowoduje, że budynki bibliotek przestaną wyróżniać się z otoczenia"48, a więc mogą utracić towarzyszącą jej funkcję i aurę. Pozostaje mieć nadzieję, że ludzie filmu i me-

${ }^{48}$ C. Hart, The Myth of Material Knowledge: Reading the Image of Library Buildings, "New Library World" 1996, vol. 97, nr 1127, s. 23-31. 
diów jak najdłużej będą wykorzystywać daną talentem moc pokazywania i przekazywania „podmiotowi cielesnemu” (jakim jest widz), że wszyscyśmy z literatury, z książek, z bibliotek. Czyż wielu z nas nie zazdrościło porucznikowi Williamowi Sommersetowi z Seven, że może noca czytać w samotności Dantego w jednej z najpiękniejszych bibliotek, i to przy Arii na strunie G Johanna Sebastiana Bacha? Aż się chce zacytować słowa Morgana Freemana skierowane do ochrony bibliotecznej: „Nigdy tego nie pojmę. Wszystkie te książki, cała wiedza świata na wyciagnięcie ręki, a co wy robicie?”

\section{BIBLIOGRAFIA}

Bana, post, <http://forum.nowyebib.info/pun/viewtopic.php?id=433>; post z 16 kwietnia 2011 roku [dostęp: 20.08.2019].

Bibliotekarka Olivia Caliban, blog „Biblioteka Edgara”, <http://biblioteka-edgara.blogspot.com/2018/08/bibliotekarka-olivia-caliban.html> [dostęp: 20.08.2019].

Castells M., Wszystko, co ma znaczenie, to wymiana impulsów w Sieci, rozm. przepr. C. Barney, „Magazyn Sztuki” 2000, nr 24.

[Dwa] 2MAN, Larry 7: Miłość na Fali, <https://www.pcworld.pl/news/Larry-7-Milosc-na-Fali,278692.html> [dostęp: 20.02.2020].

Feusette K., Sam jak pies, „Rzeczpospolita” 2004, nr 281.

Firlej-Buzon A., Absolwent kierunku informacja naukowa i bibliotekoznawstwo, „Książa i Czytelnik" 2005, nr 2.

Główka B., Nowe w bibliotekarstwie akademickim - widziane przez bibliotekarkę z dtugim stażem pracy, „Bibliotekarz” 2005, nr 9.

Górna M., To King popsut klaunom reputację, „Gazeta Wyborcza” 2019, nr 211.

Gruchała I., Katalogowanie filmów, „FIDES Biuletyn Bibliotek Kościelnych” (2004, dr. 2005), $\mathrm{nr} 1 / 2$.

Hart C., The Myth of Material Knowledge: Reading the Image of Library Buildings, "New Library World” 1996, vol. 97, nr 1127.

Helman A., Przestrzeń filmowa, [w:] Stownik filmu, red. R. Syska, Kraków 2010.

Hollender B., Reżyserki szturmem wzięty europejski festiwal, „Rzeczpospolita” 2019, nr 39.

Hopfinger M., Literatura i media. Po 1989 roku, Warszawa 2010.

Jędrych J., Ray Oldenburg i jego teoria trzeciego miejsca, „Warsztaty Bibliotekarskie” 2015, nr 1 (45), <http://warsztatybibliotekarskie.pedagogiczna.edu.pl/nr-12015-45/ ray-oldenburg-i-jego-teoria-trzeciego-miejsca/> [dostęp: 20.08.2019].

Jędrzejko P., Zamknięci w bibliotece, czyli Rozważania o metanarracjach i naukowych wizjach świata, [w:] Światła biblioteki otwartej. Rola biblioteki akademickiej $w$ kształtowaniu społeczeństwa obywatelskiego, red. D. Pawelec, M. Waga, J. Witek, Katowice 2016.

Kozina I., Rola intymności w architekturze bibliotek, [w:] Światta biblioteki otwartej. Rola biblioteki akademickiej w ksztattowaniu spoteczeństwa obywatelskiego, red. D. Pawelec, M. Waga, J. Witek, Katowice 2016.

Kyzioł A., Sierotki kontra opiekun, „Polityka” 2017, nr 2. 
Line M.B., Library Management Styles and Structures, a Need to Rethink?, „Journal of Librarianship and Information Science", London 1991, vol. 23, nr 2.

Łęcki K., Biblioteka - twierdza i raj, [w:] Światta biblioteki otwartej. Rola biblioteki akademickiej w ksztattowaniu społeczeństwa obywatelskiego, red. D. Pawelec, M. Waga, J. Witek, Katowice 2016.

Malesa R., Zawód bibliotekarza. Między przeszłościq a przyszłościa, „Folia Bibliologica” 2006/2007, t. 48/49.

Marcinkowski P., Autostereotyp czy samouwielbienie, czyli jak sami siebie widzimy, [w:] Przyszłość bibliotek w Polsce, red. J. Sadowska, Warszawa 2008.

Marcinkowski P., Bibliotekarz. Stereotyp czy wizerunek?, [w:] Tradycja i nowoczesność bibliotek akademickich, Rzeszów 2005.

Marcinkowski P., Bibliotekarz. Stereotyp czy wizerunek?, <https://repozytorium.amu. edu.pl/bitstream/10593/117/1/stereotyp.pdf> [dostęp: 21.08.2019].

Marcinkowski P., Czy bibliotekarz zna język czytelnika?, „EBIB” 2005, nr 4, <http://ebib. oss.wroc.pl/2005/65/marcinkowski.php> [dostęp: 21.08.2019].

Marcinkowski P., Czy bibliotekarze będa budowniczymi społeczeństwa informacyjnego w Polsce?, „Bibliotekarz” 2006, nr 11.

Marcinkowski P., Jak zmienić wizerunek bibliotekarza?, „EBIB” 2006, nr 2, http://ebib. info/2006/72/marcinkowski.php, [dostęp: 21.08.2019].

Michalski C., Bohater chuderlawych chłopców, „Newsweek Polska” 2011, nr 33.

Miczka T., Ostrowska E., Przestrzeń, [w:] Stownik pojęć filmowych, t. 9: Ruch, czas, przestrzen, monta $\dot{z}$, Katowice 1998.

Movie Librarians. Notable Librarians \& Librarians in Films, <http://home.earthlink. net/ movielibrarians/> [dostęp: 20.08.2019].

Mukařovský J., W stronę estetyki filmu, [w:] Estetyka i film, red. A. Helman, Warszawa 1972.

Ostaszewski J., Paradoksy przestrzeni filmowej, „Kino” 2001, nr 2.

Ostrowska E., Przestrzeń filmowa, Kraków 2000.

Parnowska M., O bibliotekarzach, bibliofilach, bibliomanach, bibliofagach i bibliotafach, „Twórczość” 2008, R. 64, nr 1.

Piosenka Nie czuję rytmu, <https://www.youtube.com/watch?v=4Dv0SQly5rE> [dostęp: 21.08.2019].

[Piosenka] Poczucie rytmu, <http://www.tekstowo.pl/piosenka,fineasz_i_ferb,poczucie_ rytmu.html> [dostęp: 21.08. 2019].

Projekt BCI - Hjoerring Public Library, <https://www.youtube.com/watch?v=04PG6nLxNcQ> [dostęp: 13.08.2019].

Robbins S.L., The Dismissal of Miss Ruth Brown: Civil Rights, Censorship, and the American Library, University of Oklahoma Press 2001.

Roszkowska D., Biblioteka „trzecim miejscem”?, „Warsztaty Bibliotekarskie” 2016, nr 2 (46), czasopismo elektroniczne, <http://warsztatybibliotekarskie.pedagogiczna.edu. $\mathrm{pl} / \mathrm{nr}-22015-46 /$ biblioteka-trzecim-miejscem/> [dostęp: 13.08.2019].

Seuss, dr (właśc. Theodor Seuss Geisel), Kto zje zielone jajka sadzone?, przekł. S. Barańczak, Poznań 2018.

Sitarski P., Rozmowa z cyfrowym cieniem. Rzeczywistość wirtualna jako przedmiot zainteresowania humanisty, Kraków 2002. 
Szczerba J., Zobaczyła, pomyślała, skłamała, „Gazeta Wyborcza” 2008, nr 32.

Szybowska U., Lista przebojów bibliotekarskich hitów na YouTubie, czyli w poszukiwaniu ukrytych skarbów, „EBIB” 2010, nr 3, <http://www.ebib.info/2010/112/a. php?szybowska> [dostęp: 13.08.2019].

Śniechowska-Karpińska A., Zgryźliwa, podobna do sepa, czyli: kto rzadzi w bibliotece w Hogwarcie?, „EBIB” 2004, nr 4, <http://ebib.oss.wroc.pl/2004/55/sniechowska. php> [dostęp: 13.08.2019].

Świątek R., Krwawy, bezlitosny macho, „Rzeczpospolita” 2011, nr 191.

Take a seat, <http://www.youtube.com/watch?v=2Dgaz6NIUFk> [dostęp: 13.08.2019].

The Insulting Librarian - Mitchell \& Webb, <https://www.youtube.com/watch?v=rqTE-ig7NhY> [dostęp: 20.08.2019].

Winiarska M., E-film jako najnowszy sposób percepcji sztuki filmowej, [w:] Internetowe gatunki dziennikarskie, red. nauk. K. Wolny-Zmorzyński, W. Furman, Warszawa 2010.

Wojtczak J., Nowe pokolenie bibliotekarzy - oczekiwania a możliwości, [w:] Marketing wewnętrzny i zarzadzanie zasobami ludzkimi w bibliotece, red. H. Brzezińska-Stec i J. Kudrawiec, Białystok 2009.

Zajdel J., Hipertekstualna struktura polskich internetowych serwisów filmowych, [w:] Internet, społeczeństwo informacyjne, kultura, red. nauk. A. Kiepas, M.S. Szczepański, U. Żydek-Bednarczuk, Tychy 2006.

Zygmunt M., Mysz uzbrojona w mysz, czyli o stereotypie bibliotekarki w społeczeństwie informacyjnym, „Biuletyn Informacyjny Biblioteki Narodowej” 2002, nr 1.

Żmigrodzki Z., Patologia biblioteczna, Katowice 1996. 